Economic gains of liberalising access to fishing quotas witin the European Union

Andersen, Jesper Levring; Nielsen, Max; Lindebo, Erik

Published in:

Marine Policy

DOI:

10.1016/j.marpol.2008.11.004

Publication date:

2009

Document version

Early version, also known as pre-print

Citation for published version (APA):

Andersen, J. L., Nielsen, M., \& Lindebo, E. (2009). Economic gains of liberalising access to fishing quotas witin the European Union. Marine Policy, 33(3), 497-503. https://doi.org/10.1016/j.marpol.2008.11.004 


\title{
Economic gains of liberalising access to fishing quotas within the European Union
}

\author{
Jesper L. Andersen, Max Nielsen and Erik Lindebo ${ }^{1}$
}

\begin{abstract}
This paper analyses the extent to which specialisation gains can be achieved by liberalising access to fishing quotas within the EU. Fishing quotas are today exchanged between EU member states at a rate of $4 \%$ of total turnover in EU fisheries. Germany, Belgium, Denmark and the Netherlands are the most active. Only one-fourth of these exchanges are permanent. With the management systems in EU fisheries differing among countries, comparative advantages in fisheries exist in member states with the best management practices. Hence, although positive but small specialisation gains exist in EU fisheries today, these gains might potentially be increased by liberalising access to fishing quotas and allowing transferability of quotas between individuals from different countries on a permanent basis. Increasing the gains might, however, affect relative stability.
\end{abstract}

Key words: Liberalising access to fisheries, specialisation, comparative advantage, economic gains, quota exchange.

JEL Classification Codes: Q22, Q27.

\section{Introduction}

Countries endowed with fish stocks possess absolute advantages in fisheries. Countries with a greater ability to exploit fish stocks possess comparative advantages in fisheries. The utilisation of the comparative advantages in fisheries gives rise to economic gains through specialisation, assuming the presence of fisheries management to avoid overexploitation. Ownership of fish resources are national, implying that utilisation of comparative advantages across countries require continuous adaptation. Quota exchange between countries is a commonly applied instrument to adaptation.

The purpose of this paper is, by means of a case study of the European Union (EU), to identify the importance of country-wise quota exchange and to assess the extent to which gains from specialisation can be achieved through liberalising access to fishing quotas. For example, what is the level of adaptation through quota exchange? Have the comparative advantages in EU fisheries been utilised or can liberalisation of access to fishing quotas raise specialisation gains? This paper analyses quota data for 2004-2006 and official quota exchange data for 2000-2006 transmitted to the European Commission ${ }^{2}$.

\footnotetext{
${ }^{1}$ Corresponding author Jesper Levring Andersen is senior adviser and Max Nielsen associate professor at the Institute of Food and Resource Economics, the Faculty of Life Sciences at the University of Copenhagen, Rolighedsvej 25, DK1958 Frederiksberg C, Denmark, e-mail: jla@foi.dk and max@foi.dk. Erik Lindebo is an economist at the European Commission, DG Fisheries and Maritime Affairs, e-mail: Erik.LINDEBO@ec.europa.eu. This work has been carried out with support from the OECD. The paper does neither reflect the views of the OECD nor the European Commission, only the personal views of the authors are presented.

2 See www.fd.dk where this information and a range of other statistical information can be found and downloaded. TAC/quota data were also available for 2000-2003, but several unreliable figures were identified, and correcting was
} 
Owing to stock externalities in fisheries, management is necessary to obtain long-run economic gains. Biological management has to ensure sustainability, whereas economic management is necessary to promote the economic efficiency of fishing. With the introduction of the 200 nautical mile Extended Economic Zone, nations had the opportunity to claim the ownership of fish stocks within their zone in the late seventies and early eighties [1, Article 56]. However in the EU, member states' fish stocks are a common resource, and therefore it is the Council of Ministers of the EU which decides on the total allowable catches (TAC) and the quota allocation for each member state. It is within the competence of each state to decide how to allocate and manage this quota. Hence, biological management is decided by the Council, based on a Commission proposal, while economic management is a member state issue.

General limits for fishing capacity and effort are adopted by the Council, while the choice of the concrete management system is decided by each member state. Several different management systems are applied in different fisheries within the member states, ranging from regulated open access, via regulated-restricted access, to property right-based management like individual transferable quota schemes. However, with a recognised overcapacity of the EU fleet [2,3], changing the management approach can help to improve the economic gains in several EU fisheries.

Economic gains can be achieved by each member state through the introduction of property right-based management [4,5,6,7]. Several right-based management systems exist in EU fisheries in various forms, from pure individual transferable quota and license systems to systems where fishing rights are indirectly transferable and capitalised in the vessels themselves.

Achieving the full economic gains within the EU, however, further requires more liberal access to fishing quotas in order to utilise comparative advantages in fisheries. In general, a country with a higher productivity than another, for a given industry, possesses a comparative advantage. The difference in productivity might be caused by several factors, including differences in skills, capital and labour costs, including access to capital investment and availability of state aids and subsidies. In fisheries, however, management is a further important determinant of productivity. Within the EU, economic management of fisheries differs considerably between the member states [8]. Therefore, productivity differences exist and member states with a good track record of economic management might possess comparative advantages in fisheries. If these comparative advantages are to result in specialisation gains, the liberalisation of access to fishing quotas would be necessary. The consequence of liberalising access to fishing quotas is that the relative stability principle fixing the quota allocation between member states might be affected. Hence, a trade-off between achieving specialisation gains and keeping a fixed quota allocation exists.

The hypothesis is that quota exchange rarely occurs and affects relative stability only to a limited extent, thereby leaving unachieved economic gains from specialisation in EU fisheries. The main reason is overcapacity in EU fisheries, implying that most economically viable quotas remain fully used by the owner country and there are only few unused quotas to exchange away. Furthermore, member state governments are not expected to make cost-benefit analyses of how much value added one group of vessels has to give up in order for another to obtain a larger value added. National quota allocations between groups of vessels are not expected to change considerably by making country-level quota exchanges. Provided that the hypothesis holds there are unused economic gains from specialisation from the existence of an EU fisheries sector, beyond those resulting from more efficient national management. If it does not hold, these specialisation gains do not exist.

considered too complex. The accession of new member states in 2004 reduced the number of quotas, especially in the Baltic Sea. Comparing the data for 2004-2006 with other sources, the available data is considered to be reliable. 
The paper is organised as follows. In section two, the quota allocation mechanism is described. In section three and four, respectively, the scale of quota adaptation and the influence on relative stability are assessed. In the last section potential specialisation gains are identified and the ways on how the gains can be achieved are discussed.

\section{Quota allocation}

The allocation of fishing rights between member states of the European Community was agreed following long negotiations on 25 January 1983 as a part of the Common Fisheries Policy [9]. This allocation is specified in the relative stability key still used today. The relative stability key had the political purpose to avoid lengthy discussion every year about allocation of the agreed Total Allowable Catches (TAC) and an industry purpose to give a reasonable security about catches and thus future planning [10]. The actual determination of the relative stability key was based on three elements. The first was historic catches based on a reference period from 1973-1978. The second was special provisions for fisheries dependent areas also known as the Hague preferences. Finally, jurisdictional losses following the implementation of the 200 nautical mile Extended Economic Zone by third countries were compensated. Complex calculations taking these three elements into consideration were afterwards performed in order to derive the "final" relative stability key.

Since 1983 there have been changes to the relative stability key, primarily following the accession of new member states. Following the revision of the Common Fisheries Policy (CFP) in 2002, the Council of Ministers decided to continue using the relative stability key despite it being argued that it was not in harmony with the principle of free movement of capital and labour within the European Union ${ }^{3}$.

Council Regulation (EC) No 2371/2002 of 20 December 2002 on the conservation and sustainable exploitation of fisheries resources under the CFP [11] notes that: "In view of the precarious economic state of the fishing industry and the dependence of certain coastal communities on fishing, it is necessary to ensure relative stability of fishing activities by the allocation of fishing opportunities among the member States, based upon a predictable share of the stocks for each member State. In other respects, that stability, given the temporary biological situation of stocks, should safeguard the particular needs of regions where local populations are especially dependent on fisheries and related activities as decided by the Council in its Resolution of 3 November 1976(4), on certain external aspects of the creation of a 200-mile fishing zone in the Community with effect from 1 January 1977, and in particular Annex VII thereto. Therefore, it is in this sense that the notion of relative stability aimed at should be understood".

In the same Regulation, Article 20 on the allocation of fishing opportunities further specifies that: "The Council, acting by qualified majority on a proposal from the Commission, shall decide on catch and/or fishing effort limits and on the allocation of fishing opportunities among member states as well as the conditions associated with those limits. Fishing opportunities shall be distributed among member states in such a way as to assure each member state's relative stability of fishing activities for each stock or fishery......member states may, after notifying the Commission, exchange all or part of the fishing opportunities allocated to them".

The quota allocated to each member state via the relative stability key can initially be seen as rather restrictive for the utilisation of the comparative advantages. However, a member state has the possibility of changing this by making quota exchanges with another member state. It is noted, however, that quota exchange should not impact relative stability per se, as they are of temporary

\footnotetext{
${ }^{3}$ EC Treaty, Article 39 Free movement of workers and Article 56 Free movement of capital [9].
} 
nature. Nevertheless, these exchanges are an indication of additional economic interests of member states' fishing industries that are not fully met by initial quota allocations to member states.

The possibility of country-level quota exchange between member states was introduced with the CFP as early as 1983 [9]. Quotas can be exchanged on a temporary basis, but continuously repeated exchange is also possible. Therefore, quota exchange can be considered both as a short run flexible instrument, but also as a long run structural instrument.

Based on stock recommendations primarily from the International Council for the Exploration of the Sea, the European Community negotiates TACs for each species and management area regulated by using overall catch limitations. Following these agreements, the EU's part of the TAC is distributed to its member states by using the relative stability key. Besides EU member states, several other countries obtain a share of the TAC such as Norway, the Faroe Islands and Russia. For example, each year Norway and the European Community reach an agreement regarding the seven shared fish stocks in the North Sea, and undertake a series of exchanges of fishing possibilities in the North Sea and Northeast Atlantic.

The agreed TAC for 2004-2006 for the whole Northeast Atlantic area for all quota species is shown in Table 1 together with the share of the EU and member states ${ }^{4}$.

TABLE 1. Initial TAC and country allocation, 2004-2006, 1,000 tonnes ${ }^{1}$.

\begin{tabular}{|l|rrr|}
\hline & 2004 & 2005 & 2006 \\
\hline TAC & 7,450 & 7,193 & 15,442 \\
- EU - Belgium & 4,745 & 4,910 & 3,617 \\
- Denmark & 30 & 31 & 31 \\
- Estonia & 1,756 & 1,511 & 766 \\
- Finland & 62 & 92 & 86 \\
- France & 81 & 105 & 124 \\
- Greece & 338 & 371 & 324 \\
- The Netherlands & 0 & 0 & 0 \\
- Ireland & 296 & 365 & 296 \\
- Italy & 207 & 234 & 198 \\
- Latvia & 5 & 5 & 5 \\
- Lithuania & 69 & 100 & 91 \\
- Poland & 25 & 37 & 33 \\
- Portugal & 156 & 193 & 177 \\
- Spain & 87 & 131 & 107 \\
- United Kingdom & 311 & 437 & 307 \\
- Sweden & 611 & 631 & 563 \\
- Germany & 211 & 259 & 253 \\
- Unallocated & 259 & 268 & 235 \\
\hline
\end{tabular}

Note:

1. The salmon TAC is measured in pieces, and has thus been converted to weight assuming the average weight of a salmon to be five kilograms.

2. The TAC more than double in 2006 mainly due to a substantial increase in blue whiting, which is a TAC only utilised to a limited extent.

\footnotetext{
${ }^{4}$ Since quotas only exist in the Northeast Atlantic Ocean and not in the Mediterranean Sea, exchanges are only performed there.
} 
An example of how the EU's part of the eight cod TACs is allocated among member states is shown in Table 2.

TABLE 2. Relative stability key for cod, percentage of EU share of the TAC.

\begin{tabular}{|l|rrrrrrrrrrr|}
\hline & BEL & DNK & DEU & IRL & ESP & FIN & FRA & NLD & PRT & SWE & GBR \\
\hline Barents Sea & & & 19.26 & & 49.79 & & 8.10 & & 10.51 & & 12.34 \\
Skagerrak & 0.27 & 82.64 & 2.07 & & & & & 0.54 & & 14.47 & \\
Kattegat & & 61.75 & 1.27 & & & & & & & 36.98 & \\
Baltic Sea & & 44.76 & 19.57 & & & 2.26 & & & & 33.41 & \\
North Sea & 3.56 & 20.45 & 12.97 & & & & 4.40 & 11.56 & & 0.13 & 46.93 \\
W-Scotland, E-Greenland, Faroe & 0.30 & & 2.84 & 15.85 & & & 30.51 & & & & 50.51 \\
Irish Sea & 1.36 & & & 65.82 & & & 3.64 & 0.36 & & & 28.82 \\
Bay of Biscay, Iberian Seas & 4.47 & & & 10.21 & & & 76.42 & 0.63 & & & 8.26 \\
\hline
\end{tabular}

\section{Quota adaptations}

Adaptations in quota occur between member states, which are not directly linked to individual fishermen. Instead quota adaptations are taken from or given to the overall member state quota level, which is then allocated to the individual fishermen accordance with the national regulation ${ }^{5}$. Three means of adaptation in the quota allocated to a member state can be identified:

1) Transfers between years

2) Revised recommendations during a year

3) Exchanges within a year

The EU legislation facilitates a flexible quota management system as specified in Council Regulation no. 847/96. If a member state has over- or underutilised some of its allocated quotas, this is generally deducted from or added to the quotas in the following year. However, the frequency of these transfers has not been possible to determine from the available data.

New information may for different reasons become available during a year, leading to a reassessment of the biological advice. This may be based on new biological survey data or revised catch statistics. Uncertain stock conditions may also imply that quotas are set during the year. This has, for instance, been the case for the sand eel fishery since 2006, where the quota is determined in May based on the year-class abundance in the previous year.

An individual member state can on its own initiative make adaptations within a year in its allocated quotas. Three types of adaptations can be identified:

1) An exchange between member states

2) An interchange within a member state

3) A transfer within a member state

Member states can exchange quotas between each other based on mutual agreements. These exchanges can cover different species and areas depending on the exact agreement. Since 2000 an interchange has only been utilised in 2001 and 2002, where Denmark converted 19,000 tonnes of sand eel in the Norwegian zone of the North Sea to Norway pout in the same area. Finally, a member state can be allowed to transfer quota from one area to another for the same species. A classic example of quota exchanges between member states is the Arcachon agreement. Since 1992, a bilateral agreement between France and Spain modifies the allocation of quotas between both

\footnotetext{
${ }^{5}$ Arrangements initiated at the private level between fishermen located in different countries only concern the fishermen involved. Such arrangements are however not generally applied.
} 
countries every year, increasing the French anchovy quota in exchange of increasing the Spanish hake quota ${ }^{6}$.

The amount of quota involved in each of the three adaptation types is shown in Table 3. A steady increase in the exchanged amounts is observed during the seven years. Compared to the first years, a doubling is observed for 2005 and 2006. Although several reasons can have caused this, the most important and likely reason is that the quotas have become more restrictive in the national fisheries, and this has increased awareness about adaptation possibilities and the desire to utilise these in the member states.

TABLE 3. Amount of member state quota adaptations 2000-2006, 1,000 tonnes.

\begin{tabular}{|l|rrrrrrr|}
\hline & 2000 & 2001 & 2002 & 2003 & 2004 & 2005 & 2006 \\
\hline Exchange & 197 & 229 & 198 & 200 & 290 & 422 & 395 \\
Interchange & & 19 & 19 & & & & \\
Transfer & 7 & 7 & 5 & 3 & 12 & 98 & 3 \\
\hline Total & 204 & 255 & 222 & 203 & 302 & 519 & 397 \\
\hline
\end{tabular}

The majority of quota adaptations are made by means of exchanges between member states, and hence this is the focus of the present analysis. There can be several reasons for such exchanges. Generally, the involved countries must be expected to obtain a benefit from making an exchange. The quotas are more or less determined individually. Therefore, it is often the case that member states run into a situation where some quotas are constraining, while others are not. If some of the constrained species are caught together with unconstrained species, this results in the fishery being closed. In order to continue the fishery, the member state can therefore try to find countries with excess amounts of the constrained species, and negotiate an exchange. Member states may also exchange for more altruistic purposes by giving unused quota away without obtaining anything in return.

\footnotetext{
${ }^{6}$ Arcachon Agreement signed in 1992 between France and Spain, under which Spain commits to exchange 6,000 tonnes of anchovy in return of quota for other species i.e. hake, cod, monkfish and sole. These 6,000 tonnes were increased to 9,000 tonnes later on. The agreement was renewed in 2003.
} 
The following tables give an overview of involvement of EU countries in exchanges ${ }^{7}$. Table 4 shows the provided quota amounts for each country, while Table 5 describes received amounts.

TABLE 4. Country distributions of exchanges, provider countries, $\mathbf{1 , 0 0 0}$ tonnes.

\begin{tabular}{|l|rrrrrrr|r|}
\hline & 2000 & 2001 & 2002 & 2003 & 2004 & 2005 & 2006 & Total \\
\hline Germany & 60 & 66 & 36 & 40 & 85 & 97 & 87 & 471 \\
Spain & 50 & 43 & 46 & 47 & 54 & 58 & 69 & 365 \\
Denmark & 23 & 26 & 31 & 18 & 28 & 49 & 69 & 244 \\
United Kingdom & 7 & 16 & 9 & 18 & 31 & 51 & 31 & 162 \\
The Netherlands & 4 & 13 & 13 & 18 & 21 & 33 & 40 & 142 \\
France & 15 & 20 & 14 & 10 & 15 & 24 & 24 & 121 \\
Sweden & 5 & 10 & 11 & 9 & 7 & 35 & 24 & 101 \\
Belgium & 13 & 13 & 18 & 17 & 12 & 13 & 15 & 101 \\
Portugal & 10 & 10 & 11 & 10 & 6 & 15 & 7 & 69 \\
Ireland & 8 & 6 & 5 & 7 & 10 & 15 & 10 & 62 \\
Lithuania & & & & & 13 & 8 & 10 & 31 \\
Finland & 2 & 7 & 3 & 7 & 7 & 5 & 0 & 30 \\
Poland & & & & & 2 & 9 & 6 & 17 \\
Estonia & & & & & & 11 & 1 & 12 \\
Greece & 0 & 0 & 0 & 0 & 0 & 0 & 0 & 2 \\
Latvia & 197 & 229 & 198 & 200 & 290 & 422 & 395 & 1,931 \\
\hline Total & & & & & & & &
\end{tabular}

TABLE 5. Country distributions of exchanges, recipient countries, $\mathbf{1 , 0 0 0}$ tonnes.

\begin{tabular}{|c|c|c|c|c|c|c|c|c|}
\hline & 2000 & 2001 & 2002 & 2003 & 2004 & 2005 & 2006 & Total \\
\hline Germany & 27 & 31 & 40 & 53 & 85 & 101 & 104 & 441 \\
\hline The Netherlands & 17 & 30 & 26 & 46 & 70 & 100 & 88 & 376 \\
\hline France & 48 & 46 & 39 & 26 & 28 & 34 & 25 & 247 \\
\hline Denmark & 59 & 53 & 27 & 14 & 18 & 34 & 23 & 228 \\
\hline Sweden & 12 & 25 & 16 & 10 & 8 & 29 & 32 & 132 \\
\hline United Kingdom & 4 & 7 & 6 & 9 & 24 & 39 & 43 & 131 \\
\hline Spain & 14 & 14 & 13 & 21 & 19 & 25 & 13 & 119 \\
\hline Ireland & 3 & 4 & 7 & 4 & 14 & 20 & 19 & 72 \\
\hline Belgium & 9 & 9 & 11 & 8 & 4 & 4 & 7 & 51 \\
\hline Finland & & 9 & 10 & 6 & 5 & 9 & 0 & 39 \\
\hline Portugal & 2 & 2 & 2 & 5 & 6 & 6 & 3 & 27 \\
\hline Lithuania & & & & & 6 & 4 & 17 & 27 \\
\hline Poland & & & & & 2 & 7 & 13 & 22 \\
\hline Estonia & & & & & & 7 & 5 & 13 \\
\hline Latvia & & & & & & 2 & 2 & 4 \\
\hline Greece & 0 & 0 & 0 & 0 & 0 & 0 & 0 & 1 \\
\hline Total & 197 & 229 & 198 & 200 & 290 & 422 & 395 & 1,931 \\
\hline
\end{tabular}

The amounts traded are of course highly influenced by the type of species involved. Measured in weight, the TACs for low value species (typically fish used for reduction) are generally much higher than the TACs for species used for human consumption. Therefore it is not surprising that fish for reduction are among the most exchanged species based on weight, cf. Table 6.

\footnotetext{
${ }^{7}$ Throughout the paper all EU member states at any given time are included. That is for 2000-2003 exchanges of 15 member states are included and for 2004-2006 exchanges of 25 member states are included.
} 
TABLE 6. Top 15 exchanged species measured in weight, $\mathbf{1 , 0 0 0}$ tonnes.

\begin{tabular}{|l|rrrrrrrr|r|}
\hline & 2000 & 2001 & 2002 & 2003 & 2004 & 2005 & 2006 & Total \\
\hline Herring & 45 & 65 & 41 & 32 & 70 & 126 & 71 & 451 \\
Jack/horse mackerel & 41 & 35 & 35 & 47 & 48 & 76 & 66 & 347 \\
Blue whiting & 8 & 24 & 30 & 33 & 55 & 66 & 130 & 346 \\
Sprat & 31 & 19 & 18 & 14 & 27 & 36 & 9 & 154 \\
Mackerel & 16 & 13 & 15 & 18 & 14 & 13 & 14 & 100 \\
Atlantic red fish & 1 & 3 & 3 & 14 & 26 & 20 & 19 & 87 \\
European anchovy & 15 & 13 & 12 & 12 & 9 & 11 & 1 & 73 \\
Cod & 7 & 7 & 8 & 3 & 8 & 17 & 14 & 63 \\
Sand eel & & 12 & 7 & & & 7 & 23 & 49 \\
Plaice & 6 & 9 & 7 & 3 & 3 & 5 & 7 & 41 \\
Hake & 11 & 4 & 4 & 3 & 4 & 8 & 6 & 39 \\
Haddock & 1 & 5 & 1 & 2 & 5 & 7 & 6 & 28 \\
Anglerfish & 4 & 5 & 5 & 3 & 3 & 5 & 3 & 26 \\
Saithe & 1 & 2 & 1 & 2 & 2 & 6 & 8 & 22 \\
Whiting & 4 & 5 & 3 & 2 & 1 & 0 & 2 & 17 \\
\hline
\end{tabular}

If we convert the conducted exchanges into value using average yearly prices ${ }^{8}$, the picture changes significantly, cf. Table 7. As expected the species used for human consumption increase their relative importance. In total, the catch value of all exchanges from 2000 to 2006 is estimated to be $€$ 1.8 billion, if they are fully utilised. This gives a yearly average of $€ 251$ million with an increasing tendency over the years.

TABLE 7. Top 15 exchanged species measured in value, $€ \mathbf{1 , 0 0 0 .}$

\begin{tabular}{|l|rrrrrrr|r|}
\hline & 2000 & 2001 & 2002 & 2003 & 2004 & 2005 & 2006 & Total \\
\hline Atlantic red fish & 2 & 4 & 5 & 32 & 25 & 82 & 27 & 176 \\
European anchovy & 26 & 20 & 24 & 35 & 26 & 40 & 2 & 173 \\
Hake & 49 & 19 & 18 & 13 & 17 & 33 & 24 & 172 \\
Cod & 15 & 15 & 17 & 6 & 16 & 37 & 32 & 138 \\
Anglerfish & 21 & 26 & 26 & 13 & 13 & 21 & 15 & 135 \\
Jack/horse mackerel & 9 & 11 & 17 & 19 & 32 & 27 & 15 & 130 \\
Sole & 9 & 14 & 8 & 7 & 14 & 23 & 27 & 103 \\
Herring & 7 & 18 & 9 & 5 & 11 & 22 & 13 & 86 \\
Northern prawn & 7 & 5 & 6 & 6 & 20 & 19 & 13 & 76 \\
Plaice & 10 & 16 & 12 & 6 & 6 & 10 & 15 & 75 \\
Norway lobster & 6 & 8 & 14 & 8 & 9 & 13 & 9 & 67 \\
Greenland halibut & 6 & 6 & 8 & 23 & 7 & 1 & 14 & 64 \\
Blue whiting & 2 & 7 & 11 & 7 & 13 & 12 & 5 & 56 \\
Mackerel & 5 & 6 & 8 & 9 & 9 & 8 & 11 & 56 \\
Megrims & 2 & 8 & 9 & 10 & 6 & 8 & 1 & 44 \\
\hline
\end{tabular}

\footnotetext{
${ }^{8}$ The prices are based on data from the New Cronos database covering seven of the main fishing countries within the EU, i.e. Germany, United Kingdom, Spain, Denmark, France, Sweden and the Netherlands. Further information about this can be obtained from the authors upon request.
} 
In Table 8 net quota exchanges measured in value are shown for each member state. It is observed that only two countries, Germany and France, lose catch value from quota exchanges. The remaining fourteen countries have all observed an increase in their catch value.

TABLE 8. Net quota exchanges at member state level measured in value, $€$ Million.

\begin{tabular}{|l|rrrrrrr|r|}
\hline & 2000 & 2001 & 2002 & 2003 & 2004 & 2005 & 2006 & Total \\
\hline Belgium & 0 & 4 & 0 & 0 & 1 & 0 & 1 & 8 \\
Germany & -8 & -15 & -7 & -45 & -21 & -51 & -18 & -165 \\
Denmark & 11 & 9 & -2 & -1 & 7 & 11 & 3 & 39 \\
Spain & 19 & 14 & 3 & 18 & -10 & 27 & 15 & 87 \\
Estonia & & & & & & 1 & 0 & 1 \\
Finland & 0 & 1 & 1 & 0 & 0 & 1 & 0 & 2 \\
France & -24 & -14 & -1 & 6 & -8 & 3 & -12 & -49 \\
United Kingdom & 2 & -4 & 0 & 7 & 4 & -4 & 2 & 7 \\
Greece & 0 & 0 & 0 & 0 & 0 & 0 & 0 & 0 \\
Ireland & 4 & 1 & 5 & 1 & 2 & 2 & 0 & 15 \\
Lithuania & & & & & 3 & -1 & 0 & 3 \\
Latvia & & & & & & 1 & 0 & 2 \\
The Netherlands & -3 & 3 & 2 & 5 & 13 & 5 & -3 & 22 \\
Poland & & & & & 2 & 1 & 6 & 8 \\
Portugal & 3 & 0 & -1 & 6 & 5 & 4 & 4 & 21 \\
Sweden & -4 & 1 & 1 & 2 & 0 & -1 & 1 & 0 \\
\hline
\end{tabular}

\section{Influence of adaptations on the relative stability key}

The turnover of the whole EU fishing fleet from all fishing areas was $€ 6.4$ billion in 2004 [13]. The annual average of exchanges made for quotas in the Northeast Atlantic Ocean was $€ 251$ million over 2000-2006, which thus comprised some $4 \%$ of the total turnover, according to Table 9 . Taking into account that a part of the total turnover originates from outside the Northeast Atlantic Ocean, exchanges formed more than the $4 \%{ }^{9}$. Germany and Belgium are heavily engaged in quota exchanges, both as providers and recipients. The importance of quota exchanges for Denmark and the Netherlands are also above the EU average. Several other member states are engaged in exchanges around the average rate of $4 \%$.

The difference between providing and receiving measures the net-effect of exchanges on relative stability. The potential German turnover falls by $12 \%$ compared to what could have been achieved provided that Germany had used the quotas themselves. The Lithuanian, Polish and Dutch turnover are positively affected, increasing by $6 \%, 4 \%$ and $3 \%$ respectively. Turnover of all other member states are affected by $2 \%$ or less. Hence, except for Germany quota exchanges have a limited effect on relative stability.

\footnotetext{
${ }^{9}$ Assuming that Italian and Greek turnover originates from the Mediterranean Sea, that half the Spanish turnover originates outside the Northeast Atlantic Ocean and that a quarter of Portuguese and French turnover originates outside that area, exchanges accounted for $7 \%$ of turnover obtained from activities in the Northeast Atlantic Ocean.
} 
TABLE 9. Quota exchanges at member state level as percentage of turnover, 2004.

\begin{tabular}{|l|r|rrr|}
\hline & Turnover (€ Million) & \multicolumn{3}{|c|}{ Exchanges (\% of turnover) } \\
\cline { 3 - 5 } & & Provider & Recipient & Difference \\
\hline Germany & 176 & 34 & 22 & -12 \\
Belgium & 86 & 15 & 16 & 1 \\
Lithuania & 52 & 6 & 12 & 6 \\
Denmark & 352 & 7 & 9 & 2 \\
The Netherlands & 380 & 5 & 8 & 3 \\
Poland & 40 & 4 & 8 & 4 \\
France & 754 & 5 & -1 \\
Finland & 21 & 6 & 4 & -1 \\
United Kingdom & 740 & 5 & 4 & 0 \\
Ireland & 194 & 4 & 5 & 2 \\
Spain & 1,500 & 3 & 3 & 0 \\
Portugal & 347 & 3 & 2 & 1 \\
Sweden & 91 & 1 & 2 & 1 \\
Greece & 291 & 1 & 0 & 0 \\
Estonia & 9 & 0 & 0 & 0 \\
Latvia & 19 & 0 & 0 & 0 \\
Italy & 1,380 & 0 & 0 & 0 \\
\hline Total & 6,432 & 0 & 4 & 0 \\
\hline
\end{tabular}

Source: Turnover figures originate from [13]

The importance of quota exchanges differs among species, however, as shown in Table 10 . Measured as a percentage of total EU catches in the Northeast Atlantic Ocean, redfish, anchovy, horse mackerel and blue whiting are exchanged to the largest extent. Reasons include that the quotas of these species might not be fully utilised. Furthermore, it appears that herring and demersal species like cod, hake, anglerfish, haddock and plaice are also exchanged to some extent. Hence, larger vessels dependent on industrial species, such as herring and mackerel, are particularly reliant on the exchanges, although vessels generally dependent on demersal fish also have an interest in exchanges. 
TABLE 10. Quota exchange as percentage of total EU catch for the Top 15 exchanged species.

\begin{tabular}{|l|r|r|}
\hline & $\begin{array}{r}\text { Catch 2004 } \\
(1,000 \text { tonnes })\end{array}$ & Exchanged (\%) \\
\hline Atlantic red fish & 27 & 46 \\
European anchovy & 29 & 36 \\
Jack/horse mackerel & 222 & 22 \\
Blue whiting & 375 & 13 \\
Hake & 40 & 14 \\
Anglerfish & 29 & 13 \\
Herring & 737 & 9 \\
Haddock & 63 & 6 \\
Whiting & 29 & 8 \\
Plaice & 78 & 8 \\
Cod & 151 & 6 \\
Saithe & 51 & 6 \\
Sprat & 608 & 4 \\
Mackerel & 390 & 4 \\
Sand eel & 338 & 2 \\
\hline
\end{tabular}

Note: Annual average of exchanged quotas 2000-06 in percentage of total EU-25 catches in tonnes in the Northeast Atlantic Ocean 2004.

Source: Eurostat New Cronos Database.

This can be compared to the annual transfer of quotas in the national individual transferable quota systems in Iceland, which on average traded 38\% of the total quota in 2006-2007. For the three main species of cod, shrimps and redfish, quota trade was $26 \%$, $30 \%$ and $35 \%$ respectively [14].

Quotas can only be exchanged on a temporary basis for one year. However, repeated quota exchanges can be made, implying that the exchanges obtain a more permanent character. To identify exchanges of almost permanent character, the share of exchanges made repeatedly in the same species in the same area, and between the same provider and recipient countries, are identified. The share of repeated exchange is identified in Table 11. Exchanges made in the beginning of the year where quotas are not yet constraining reveal more permanent character than if done later in the years where quotas become constraining.

TABLE 11. Quota exchanges, allocated to time of year and number of years done.

\begin{tabular}{|l|rr|rr|}
\hline \multirow{2}{*}{} & \multicolumn{2}{|c|}{ First Quarter } & \multicolumn{2}{c|}{ Whole year } \\
\cline { 2 - 5 } & 1,000 tonnes & Percentage & 1,000 tonnes & Percentage \\
\hline 7 & 178 & 20 & 382 & 20 \\
6 & 147 & 17 & 117 & 6 \\
5 & 24 & 3 & 311 & 16 \\
4 & 71 & 8 & 259 & 13 \\
3 & 182 & 21 & 267 & 14 \\
2 & 114 & 13 & 327 & 17 \\
1 & 159 & 18 & 267 & 14 \\
\hline Total & 877 & 100 & 1,931 & 100 \\
\hline
\end{tabular}

It appears that 877,000 tonnes of the total exchanges of $1,931,000$ tonnes were exchanges in the first quarter of the year. Of these exchanges, $20 \%$ were repeated in all the seven years and $17 \%$ repeated in six of the years. These exchanges have permanent character. Of the exchanges made 
over the whole year, $20 \%$ were made in all seven years and a further $6 \%$ in six of the seven years. These exchanges have almost permanent character. Hence, around one-fourth of the exchanges have permanent or almost permanent character.

\section{Discussion and conclusions}

With national fisheries management systems differing considerably between EU member states in allowing continuous minimisation of costs through transferability [12], some member states possess comparative advantages in fisheries. Given the level of quota exchanges of $4 \%$ of total turnover, these comparative advantages are used to obtain gains from specialisation, since member states are presumed to participate in exchanges only if they obtain a gain from doing so. Compared to the Icelandic situation, this $4 \%$ is low. Hence, positive but low specialisation gains are revealed.

There are several reasons for the low specialisation gains. One is that member states need to exchange quotas away. In a situation with overcapacity where member states use several of their quotas fully, they might not have anything to exchange away. A second reason is that exchanges are of relative low importance for the single fishermen if country-level quota exchanges are allocated equally among fishermen. A third reason might be the lack of knowledge of the exchange opportunity among fishermen.

Given the low level, further specialisation gains can still be achieved with exchanges between governments on a temporary basis, where it is necessary to provide unused quotas in order to receive extra quotas. However, as we have seen, it is not possible for the single fishermen to optimise activities by purchasing quotas permanently from foreign fishermen. Furthermore, in a situation where there is overcapacity, member states might not have quotas to exchange away implying that the present quota exchange instrument might not work efficiently. Therefore, unachieved specialisation gains exist in EU fisheries.

The maximum specialisation gains can be achieved with full liberalisation of access to fishing quotas within all EU member states. This could also allow exchanges directly between individual fishermen from different member states in the form of transfers of quotas in exchange for money. Thereby, instead of claiming that one quota shall be exchanged for another, and that quota adaptations need to form part of the general management system, fishermen can organise their fishing activity and utilise their individual comparative advantages across borders. Allowing individual transfers would also do away with complicated and time-consuming quota exchanges between member state authorities. Furthermore, achieving the maximum specialisation gain also require that permanent transfers are allowed. Thereby, it will be possible for the individual fishermen to plan long-term investments after a quota purchase, instead of planning only one year ahead.

Specialisation gains can also be achieved at a more limited scale, either by allowing only some of the above mechanism or by allowing them only for certain fleet segments, areas or member states. Elements of such a policy already appear in the EU. In Denmark, individual quota exchanges in herring were allowed in 2006, giving the individual fishermen the opportunity of exchanging quotas with other member states. In 2007, individual quota exchange of mackerel and industrial species across borders were also allowed. Furthermore, elements of such a policy is applied in the recently renewed agreement on EU fishing in Greenland waters, which allow unused quotas of different member states to be transferred to other EU fishermen [15]. Elements of a policy promoting specialisation gains gradually could also be constructed by allowing individual crossnational permanent quota transfers within a specified fleet segment or area. For example, one could start by allowing such transfers among large vessels operating over long distances, since they gain 
from simultaneous access to waters in several member states. Another option is to allow individual cross-national permanent quota transfers within a specified area. For example, the northern hake fishery in the Northeast Atlantic or fisheries governed by regional fisheries organisations could provide an opportunity for fishermen in a well defined area to set up a tradable quota system. Implementing these options could increase gains from specialisation, but might in effect also touch on the basic principle of relative stability.

Allowing individual cross-national permanent quota transfers might further imply that member states indirectly obtain an incentive to improve policies aiming at improving economic efficiency. For example, by allowing transferability, fishermen from member states with such policies implemented might be able to purchase quotas from fishermen from member states without such management. The reason is that fishermen from member states with good management practices possess comparative advantage in fisheries and can therefore probably outcompete fishermen with less well-functioning management systems.

Setting up a market within the EU, where individual fishermen can exchange quotas, will need to consider several key aspects in order to obtain a well-functioning market that is capable of extracting the highest economic gains. In addition to the initial allocation of quotas to the individual vessels, transaction costs, non-profit maximising behaviour and market failures like concentration, illegal behaviour and imperfect information, it is also necessary to look at the administrative design of the market. The administrative design includes considerations regarding market structure, participants, information and instruments.

The structure of the market can either be in form of centralised market, where all exchanges have to be made through one single exchange authority, or a decentralised market, where individuals themselves find who to exchange with. Defining who can buy and sell quotas is important to consider. Besides the fishermen, it has in some situations been discussed whether other people should be allowed to participate in the market. However, allowing organisations and citizens to participate can potentially impede the achieving of an economically efficient situation [16], although brokers may help to 'lubricate' the market [17]. It is also important that potential buyers and sellers have perfect information on price and availability of quotas. As within financial markets, several different types of instruments can be allowed in order to increase flexibility and reduce risk. Examples of such instruments could be futures, insurance pools and leasing and banking possibilities [18].

Thus besides initiating a quota exchange market, there are a range of other issues that need further consideration in order to obtain the highest economic efficiency. 


\section{References}

[1] United Nations. Convention on the Law of the Sea. Rome; Italy; 1982; www.un.org/Depts/los/convention_agreements/texts/unclos/unclos_e.pdf.

[2] Sissenwine M, Symes D. Reflections of the Common Fisheries Policy. Report to the General Directorate for Fisheries and Maritime Affairs of the European Commission; July 2007.

[3] European Court of Auditors. Special report no. 7 on the control, inspection and sanction systems relating to the rules on conservation of Community fisheries resources together with Commissions replies; 2007.

[4] Crocker TD. The structuring of atmospheric pollution control systems. In Wolozin H (ed.). The Economics of Air Pollution. New York: Norton; 1966.

[5] Dales JH. Pollution, property and Prices. Toronto: Toronto University Press; 1968.

[6] Montgomery WD. Markets in licenses and efficient pollution control programs. Journal of Economic Theory 1972; 5: 395-418.

[7] Squires D, Campbell H, Cunningham S, Dewees C, Grafton RQ, Herrick SF, Kirkley J, Pascoe S, Salvanes K, Shallard B, Turris B and Vestergaard N. Individual transferable quotas in multispecies fisheries. Marine Policy 1998; 22(2): 135-159.

[8] Organisation of Economic Cooperation and Development. Review of Fisheries in OECD Countries: Volume 1: Policies and Summary Statistics. Paris; France; 2005a.

[9] Council Regulation (EC) No 170/1983 of 25 January 1983 establishing a community system for the conservation and management of fishery resources. Official Journal of the European Communities, 26, L24, 1-13, 27.1.1983.

[10] Holden M. The Common Fisheries Policy. First Edition. Oxford, England: Fishing News Books; 1994.

[11] Council Regulation (EC) No 2371/2002 of 20 December 2002 on the conservation and sustainable exploitation of fisheries resources under the Common Fisheries Policy. Official Journal of the European Communities L 358/59, 31.12.2002.

[12] Organisation of Economic Cooperation and Development. Further examination of economic aspects relating to the transition to sustainable fisheries. Report from the Directorate for Food, Agriculture and Fisheries; Fisheries Committee. Paris; France; 2005b.

[13] Anon. Economic performance of selected fishing fleets. Annual report from Economic Assessment of European Fisheries 2005. (FISH205/12); http://old-stecf.jrc.it/sgeca/eaef/2005final.pdf; 2006.

[14] Icelandic Directorate of Fisheries. Transfers of quota between vessels 2006-2007. Available at www.fiskistofa.is/en/.

[15] Council Regulation (EC) No 753/2007 of 28 June 2007 on the conclusion of the Fisheries Partnership Agreement between the European Community on the one hand, and the Government of Denmark and the Home Rule Government of Greenland, on the other hand.

[16] Bohm P and Russell, CS. Alternative Policy Instruments. In Kneese AV and Sweeney JL (ed.). Handbook of natural Resource and Energy Economics, Volume 1. North Holland; 1985.

[17] Hahn RW. Promoting efficiency and equity through institutional design. Policy Sciences 1988; 21: 41-66.

[18] Rose A and Tietenberg TH. An international system of tradable CO2 entitlements: Implications for economic development. Journal of Environment and Development; 2(1): 136. 